\title{
EDUCATION VERSUS INDOCTRINATION: CONTEXTUALISING THE CRISIS IN HIGHER EDUCATION IN SOUTH AFRICA
}

\author{
T. Petrus \\ Faculty of Social Sciences and Humanities \\ University of Fort Hare \\ Alice, South Africa \\ e-mail: tpetrus@ufh.ac.za
}

\section{ABSTRACT}

Since the emergence of the national protests at Higher Education Institutions (HEls) in South Africa in 2015 , both the public media and social media platforms were inundated with debates justifying the credibility and validity of the protests. It appears that the public and social media had succeeded in swaying public opinion in favour of the protests, as much media attention was focused on portraying the protests in the same manner as those of June 1976, namely that these were students fighting for equality in education, similar to those of 1976. However, since the protests hit their peak in 2015, and even through 2016, what have we learnt about the crisis in higher education that the protests have created? First, is there a crisis? Second, do the protests reflect the reality of the state of education in South Africa, namely, that institutions no longer seek to educate, but to indoctrinate? These are the key questions addressed in this article.

Keywords: decolonisation; education; Fees Must Fall movement; Higher Education Institutions (HEls); indoctrination; South Africa; US

\section{INTRODUCTION}

Since the national student protests of 2015, the Rhodes Must Fall and Fees Must Fall movements have left their mark on the higher education landscape. It is well-known that efforts have been made to transform the higher education sector in South Africa since the 1990s. Higher education was one of the key areas that the new post-1994 national government targeted for transformation in order to reverse the effects of apartheid's segregated education policies. More significantly, higher education was identified by the then newly established National Council on Higher Education (NCHE) as a key factor in the reconstruction and development of post-apartheid South African society. According to Reddy $(2004,34)$, "The NCHE was established in 1995 with the broad mandate to advise the Minister of Education on restructuring higher education to contribute towards reconstruction and development".

Arguably, transformation at HEIs since the 1990s has been slow at best. It could be argued that it was this slow pace of transformation, as perceived by some, that catalysed the national protests that started in 2015. The push for rapid transformation since 2015 could be seen as 
having occurred through three interconnected phases. The first phase, Rhodes Must Fall, began in March 2015. This was then followed by the second phase, Fees Must Fall, in October 2015. These protests lost some momentum during the first half of 2016, but were then revived in August 2016. The third and current phase is the Decolonisation of Higher Education Movement. It should be noted that, these three phases, have been identified purely for analytical reasons, rather than being a true reflection of reality. In reality, these phases have overlapped quite extensively, making it difficult to actually determine where one phase ended and the other began. Hence, there is no clear distinction between the phases in reality.

It could be argued that the national protests created a crisis in higher education; one that is ongoing. However, some argue that there is really no crisis, and that these events are a planned strategy to transform HEIs throughout the country. This article argues that, to some extent, there is a crisis in higher education. While reversing colonial influences on higher education, as well as promoting equality of access for all appear to be the main reasons for the transformation agenda, the author argues that the crisis goes deeper than these.

The central purpose of the discussion is to determine the extent to which the protests and their consequences were the result of the tension between education and indoctrination. The discussion seeks to address this issue by referring to the education versus indoctrination dichotomy. The author illustrates that the root of the crisis lies in the over-simplistic view that transformation can result merely from the removal of perceived colonial symbols, and replacing existing curricula and structures with non-colonial ones. It is the author's contention that both colonialism, as well as decolonisation, have indoctrinatory influences. It is particularly decolonisation, if not approached with caution, that may serve to reinforce the very same indoctrination that opponents of colonialist education have criticised.

In order to illustrate the above argument, the author first provides some explanation of the concepts of education and indoctrination. This is followed by a brief discussion of how the education versus indoctrination dichotomy impacts American higher education. This is provided as an example to show what could potentially occur in South African HEIs if the efforts to decolonise higher education are not handled cautiously. The final part of the discussion elaborates on the South African context.

\section{DEFINING EDUCATION}

The distinction between education and indoctrination is critical in order to determine to what extent the dichotomy between the two impacts on perceptions of what the purpose of higher education is intended to be. The conceptualisation of these terms has also been a feature of much of the scholarship addressing education issues. Consequently, various scholars have 
sought to define and explain these concepts since, to a very large extent, they lie at the heart of what the education system is supposed to achieve.

The term education is often used in a very broad sense, with various interconnected aspects. For some, education is understood generally to mean teaching, that is, the process whereby a teacher transfers knowledge to a learner or student. For others, education refers to the systems and structures put in place to enable the transfer of knowledge. Scholarly definitions of education have sought to provide very specific understandings of the concept. According to Hocutt $(2005,36)$, "Education seeks to inculcate knowledge, belief in proven truth". This understanding views education as the vehicle through which objective proven knowledge is transferred. Education is thus not supposed to be influenced by subjective beliefs about what is known, but should only concern itself with the transfer of proven knowledge. In another definition, McDonough $(2011,721)$ views education as a type of initiation, which he defines thus:

"Initiation is a pedagogy meant to help students work creatively and progressively within a particular normative and symbolically constructed field, especially in response to both internal and external challenges. It is a pedagogical means to both transmit a knowledge of a tradition by teaching students to master a symbolic code and repertoire, and also to engage them in the development of their own capacities to manipulate that code to create alternative pronouncements and judgments in the face of historical and normative challenges to the system."

The above view conceptualises education as a rite of passage of sorts, in which students transition from a phase of not knowing to one of knowing. However, it is important to note that education is not only responsible for transferring knowledge. It is also critical in enabling the student to use the acquired knowledge to address challenges in the prevailing overarching system in which the student exists and is a part of.

A third definition echoes McDonough's view, that education is meant to enable a student to think critically about the environment or system in which he/she exists. According to Ioana and Cracsner (2016, 561), "Education involves learning and growth, it implies the difference between truth and lie, but above all, education means critical thinking on the content of the received information". In other words, similar to McDonough's view, education should assist in the development of a student, thereby facilitating his transition from one phase to another. Also, education should not only enable students to learn to think critically about the environment, but should also enable them think critically about the very knowledge or information that is received. Thus, the knowledge that is transferred should not merely be accepted without question but should be subject to scrutiny and critical evaluation, as these are as much part of the educational process as the transfer of knowledge. 
It is crucial to note that the above examples constitute only three of a multitude of academic perspectives on education as a concept. It is beyond the scope of this article to delve into great detail regarding the complexities inherent in the concept, as well as further distinctions within education that could be made, such as the difference between education and schooling; differences between teaching and facilitation of learning; distinctions between lower and higher education; or the differences between old and modern education. The use of the above definitions was intended to foreground two important aspects that are relevant to the current discussion, namely education as the transfer of knowledge, and education as critical thinking. Both of these aspects are relevant especially when attention is focused on the concept of indoctrination, and how it differs from education.

\section{DEFINING INDOCTRINATION}

The concept of indoctrination is often used in a negative sense to refer generally to a process whereby an authority structure, whether an individual, group, government, state or agency, seeks to impose a set of beliefs on individuals or groups in such a manner that the questioning of those beliefs is not tolerated. In most cases, indoctrination is associated with extremist or fundamentalist religious or political ideological views. However, it appears that what is often thought of as indoctrination may also be applied within the context of education. In this sense, scholars have sought to distinguish between education and indoctrination, with many arguing that educational institutions should guard against becoming vehicles of indoctrination.

In the current discussion, it is necessary to clarify what the concept of indoctrination implies within the context of education. According to Hocutt $(2005,36)$, as opposed to education, indoctrination means "to instruct in a body of doctrine; to teach to accept a system of thought uncritically; [it] seeks to inculcate belief which may or may not be true". This definition implies that indoctrination is very much a one-directional process of teaching that utilises very little input from the learner/student. The latter is expected to accept what is being taught without question.

Echoing the sentiment of Hocutt (2005), McDonough (2011) provides a similar understanding of indoctrination. For McDonough (2011, 707), "Indoctrinatory pedagogies present existing cultural codes... as the authoritative determinants of action and judgment". This definition implies the notion of indoctrination as an unquestioning acceptance of a dictated perspective or view, but it also introduces the concept of authority. In other words, indoctrination typically involves an entity, group, individual or institution that assumes the authority to impose its view on those it seeks to indoctrinate. By virtue of its authoritative status, whether real or imagined, the indoctrinator persuades the indoctrinated to accept what they are 
told uncritically. It is often argued that, in the political context, totalitarian regimes utilise the authority of the state, which includes the use of force and propaganda, to impose the "official" view or perspective that those in power wish the populace to accept. As Tan $(2011,3)$ puts it, "Indoctrination has been seen as the handmaiden of totalitarian regimes and their coercive educational methods ...".

In line with the views of Hocutt (2005) and McDonough (2011), Ioana and Cracsner (2016) propose their view of indoctrination. For these scholars, "Indoctrination is intended to influence targets to believe in what they are told without questioning the veracity or authenticity of the conveyed information" (Ioana and Cracsner 2016, 561). Hence, again the notion of indoctrination involving the uncritical acceptance of what is taught is reflected in this definition. The interesting term to highlight in Ioana and Cracsner's definition is the term "targets". In the view of these scholars, indoctrination is aimed at targets, implying that it is a weapon that can be used against targets (i.e. people) in pursuit of a particular agenda. Hence, unlike education which is designed to develop, empower or enable, indoctrination seeks to weaponise and mass mobilise a group or sections of a population, if not the whole population, to follow a particular agenda, and coerce those who would dare questioning this agenda.

A more controversial term that is sometimes used synonymously with indoctrination, is the concept of brainwashing. According to the Encyclopaedia Britannica (2018), brainwashing, also known as coercive persuasion, is a "systematic effort to persuade nonbelievers to accept a certain allegiance, command or doctrine". This is achieved through the manipulation of the social or physical environment, in which 'an attempt is made to destroy loyalties to any unfavourable groups or individuals... and to develop loyalty and unquestioning obedience to the ruling party" (Encyclopaedia Britannica 2018). The term is often used colloquially to refer to the techniques of advertisers and mass media to influence public perceptions in a certain direction. However, the similarities to indoctrination are reasonably clear. There is the element of imposition of a particular perspective using methods or techniques that discourage critical thinking. The notion of coercion is also a common aspect, where methods such as punishment or social exclusion, among others, may be used to force unquestioning acceptance of a particular agenda or ideology.

\section{THE RELATIONSHIP BETWEEN COLONISATION AND INDOCTRINATION}

The historical context of colonialism throughout the world reveals a close connection between colonisation as process and indoctrination. Colonisation in the African context is no exception. For example, Mart $(2011,190)$ argued that it was a deliberate strategy of colonising countries to implement their own education systems in their colonies. This allowed the colonisers to 
reinforce their physical control over their colonial subjects with mental control. According to Mart (2011, 190), “The colonizer's educational goal was to expose Africans to a superior culture". Implied in this process is the indoctrinatory effect of colonial education. The purpose of colonial education was to incorporate African societies into a Eurocentric educational system that served the dual purpose of, firstly, reinforcing the superiority of Western culture and society in the minds of the colonial subjects, and secondly, socially conditioning these subjects to distance themselves from their own cultures.

The above is echoed in the arguments by Heleta (2016) regarding curricula in South African universities. The scholar argues that university curricula remain Eurocentric and thus continue to perpetuate the indoctrination of "white and Western dominance and privilege ..." (Heleta 2016). Furthermore, colonial education imposed Eurocentric worldviews while subjugating everything else, including indigenous African knowledge. Thus, similar to Mart above, Heleta clearly establishes a link between the colonisation agenda and indoctrination of the colonised, particularly through the vehicle of education.

\section{SOME EXAMPLES OF EDUCATION VERSUS INDOCTRINATION IN THE US}

In order to determine to what extent the education versus indoctrination dichotomy is prevalent in the South African higher education context, it is necessary to first shift focus to another region, namely the US. It appears that the US is currently engaged in an ideological battle that is reflected in the education system. It is specifically the higher education sector that is affected by this battle, as many campuses appear to be divided along ideological lines, which in turn impacts teaching and learning, as well as administration and management.

It should, however, be noted that much of the literature that exposes the perceived indoctrination at US tertiary institutions is predominantly right-wing and conservative in orientation. Articles are, therefore, written to support an ideological position that opposes what is viewed as the liberal and left-wing ideology that seemingly now dominates US universities. Hence, articles such as that by Crouere (2016) are critical of the "liberal indoctrination" that "trumps education at US colleges". Crouere (2016) describes higher education in the US as being "in crisis", because of, among other things, the "toxic atmosphere on campuses". What he calls the "liberal group-think" on issues that have divided liberals and conservatives for years, has led to the silencing of alternative views on these issues. Thus, Crouere (2016) concludes,

"On our college campuses, today, politically correct professors and liberal proselytization are protected, while whistle-blowers and open debate are condemned. It is time for parents to start questioning the wisdom of paying high tuition costs for indoctrination, not education." 
The sentiments expressed by Crouere echo those espoused by Kenny (2013). In another conservative publication, The New American, Kenny $(2013,23)$ argues that "More and more, colleges are becoming venues where left-wing professors attempt to indoctrinate students with liberal views, instead of focusing on academics". The issue of the sanctioning of both academics and students who deviate from the mainstream liberal narrative is also addressed in the article. For Kenny $(2013,24)$, the indoctrination process already begins during the students' first-year orientation:

"Yet in many schools the indoctrination begins well before the incoming freshmen enter their first college classes. Orientation programs are often another name for indoctrination into a 'progressive' worldview that requires the student to drop as mental contraband any allegedly racist, reactionary, chauvinistic, or 'homophobic' views he or she may have contracted like a communicable disease ...."

Teaching curricula are also impacted by the ideological struggle, and are expected to reflect the prevailing liberalist position. Again, according to Kenny $(2013,25)$, "Everything from Theater to Philosophy to History to English has, in effect, become sociology .... Teaching subject matter has become less important than teaching a very political perspective." This suggests that the mainstream ideological view permeates teaching and learning in US universities and colleges.

The pervasive influence of ideological positions on academic teaching and curricula at US institutions has been criticised by scholarly associations. For example, in April 2012, the National Association of Scholars (NAS) published a report criticising the impact of political ideology on curricula at the University of California. In the report, the authors took issue with what they called the "corrupting effect of political activism" on the curricula on all of the institution's campuses. The problems created by political ideology in the university were identified and summarised as follows:

“... that requirements for coursework in American history and institutions have been dropped; that writing courses often stress writing far less than tendentious political topics; that prescribed books are frequently no more than journalistic presentations of a simple political message instead of the more complex writings appropriate to an academic context; and that faculty teach what to think rather than how to think: that is, they demand correct attitudes and beliefs of students more than they require independent reading and thought" (NAS 2012, 1-2).

In addition to the above, the report gave various reasons why the university should not be used for political purposes (NAS 2012, 4-9). Among these reasons was the notion that allowing a particular political agenda to dominate in the university leads to a "lack of openness to competing ideas" (NAS 2012, 6). By juxtaposing the ways in which an academic scholar and political activist may look at a particular issue, the report stressed how the latter may encourage 
indoctrinatory thinking. Unlike the scholar who critically examines every possible alternative explanation for a specific problem or issue, and weighs up the merits and weaknesses of each, the political activist, by contrast, refuses to examine critically his/her own position, and seeks to dismiss alternative explanations or positions (NAS 2012, 6). Consequently, “Academics live by competing ideas and explanations. When activists try to suppress all views but their own, their intolerance is ... on display ... [and] they are showing ... that they are unable to function as academic thinkers ..." (NAS 2012, 7).

The final part of the NAS report spells out the potential consequences of an institution that allows a dominant political agenda to remain unchecked. These consequences were categorised as educational and social. Some of the most serious consequences included a "sharply inferior higher education" (NAS 2012, 60), characterised by a lack of basic skills, unpreparedness for the workplace (NAS 62-63), the spill-over effect of poor preparation of students into high schools (NAS 65-67), and the contradiction that the radical agenda serves not to help disadvantaged groups, but rather continues to be destructive for them (NAS 69).

Despite the arguments raised in the NAS report, the leftist political dominance in US institutions seems to have continued. In one of the more recent reports on the apparent indoctrination on American university campuses, New York Post writer F. H. Buckley criticised what he viewed as the Obama administration's attempt to indoctrinate students through “progressive 'New Civics' programs” (Buckley 2017). Quoting from a more recent study by the National Association of Scholars, Buckley (2017) stated the following:

"The goal of the New Civics movement ... is to teach students 'that a good citizen is a radical activist,' putting 'political activism at the center of everything that students do in college, including academic study, extra-curricular pursuits, and off-campus ventures'. Instead of a civics education that studies the foundations of American government, New Civics teaches students 'how to organize protests, occupy buildings, and stage demonstrations'."

Based on the above quote, it appears that the ideological battle on American campuses is not over. The education versus indoctrination dichotomy is in full swing. Taking an ideological position determines one's view of which side of the dichotomy one is on. Hence, those subscribing to the dominant ideological position would probably regard themselves as educating students, while those on the opposite side view the system as indoctrinating students.

The purpose of briefly discussing the American higher education context is to show that the prevailing or dominant political ideology has a significant impact on any educational system, regardless of whether the context occurs in a Western or non-Western country. The US is held by many to be the epitomy of the modern Western nation, yet it is not spared the ideological contestation between the dominant narratives of liberalism and conservatism in its 
higher education system. The above discussion has intended to illustrate how the American higher education landscape has been affected by this contestation. In similar vein, if it is accepted that the South African higher education landscape finds itself in the midst of an ideological contestation between Eurocentric and Afrocentric thinking, each attempting to gain control of the education system, then there is something to be learnt from the American experience. This lesson, I argue, is that any ideological position that becomes the dominant narrative that affects the education system, has the potential to indoctrinate, because it is the dominant ideological position.

\section{COLONIAL SYMBOLOGY AND DECOLONISATION: EDUCATION VS INDOCTRINATION IN THE SOUTH AFRICAN CONTEXT}

A critical question that arises from the situation in US universities, and which has become highly pertinent in the South African context, is the extent to which South African higher education institutions are similarly engaged in an ideological struggle. It could be argued that there are various similarities and differences between the US and South African higher education contexts. One similarity, for example, is that South African institutions have also become embroiled in an ideological struggle, and while the contestation is not between liberalism and conservatism, as in the US, it does appear to be a struggle between colonial education and Africanised or decolonised education. Likewise, a possible difference between the US and South African contexts is that while, in the former, the ideological contestation is marked mostly by institutional, administrative and academic resistance to views contrary to the dominant narrative, in the latter the contestation has manifested in national student protests, mostly characterised by violence, and even shutdowns of campuses.

The Rhodes Must Fall movement, regarded by many as the precursor to Fees Must Fall, essentially foregrounded an ideological contestation between colonial influences on education and decolonised education. Beginning in March 2015 at the University of Cape Town (UCT), the movement targeted the removal of symbols of colonialism, with protesters particularly focused on the removal of the statue of Cecil John Rhodes. This objective was achieved about a month later when the Rhodes statue was in fact removed. The anti-colonial sentiment spread as far as Oxford University in the UK, where similar efforts were made to have Rhodes' statue at Oriel College removed. However, the significance of this movement, especially in the South African context, was illuminated by a British commentator, who stated the following:

"[I]t is the issue of the statues, and the allegations that the students involved wish to rewrite history to suit their sensitivities, that have attracted controversy .... These larger ambitions of the movement - that is, to bring out into the open institutional racism in university life in South Africa 
and Britain, and to decolonise education - speak to concerns that many have had for a while." (Chaudhuri 2016).

One particular point made by the commentator, namely that the protesting students sought to rewrite history, requires further discussion. The issue of the removal of statues raises questions about the symbology of history. Correctly, Chaudhari (2016) stated that the protesters wished to symbolically eradicate the colonial history of the university, and, by implication, the colonial history of South Africa, by removing what they considered a quintessential symbol of that colonial history. But it was not only the removal of the symbol of colonialism. Also critical was the replacement of those colonial symbols with new decolonised symbols, thereby creating a new history, one that was symbolically devoid of colonialism. As mentioned earlier, this process of rewriting history through the removal of selected symbols raises issues. Among these is the question of whose history matters and whether the removal of historical symbols is a denial of history. If so, then what are the implications of such denial?

The above questions are relevant because they raise further questions about the perceived ideological bias that permeates higher education, and how this relates to the education versus indoctrination dichotomy. This also directly and indirectly relates to the other point of the movement, namely to expose institutionalised racism at so-called colonial institutions. The call for a decolonisation of colonial institutions implies that the perceived colonial ideological basis that underpins the management, administration and teaching at universities such as UCT, has contributed to the indoctrination of students into a Western colonialist way of thinking about society and the world. Thus, the Rhodes Must Fall movement appeared to be taking a stand against Eurocentric indoctrination of African students and staff. This indoctrination engendered a perception that "a skewed system was normal" (Chaudhuri 2016), thereby normalising the continued disadvantaging of African students and staff. The resistance to this skewed system thus took the form of, among other things, a rejection of perceived colonial or Eurocentric curricula as education, and the call for such curricula to be replaced with so-called decolonised curricula.

The call for the decolonisation of HEIs is the culmination of various efforts at transformation in South African universities that had been attempted since the 1990s. According to Du Preez, Simmonds and Verhoef $(2016,2)$, although there had been calls by student organisations for change in higher education prior to 1994, it was only after the formal transition that there was a "real impetus for change to a more open, relevant and nondiscriminating higher education system". As such, these scholars identified two fundamental policy documents that formed the basis for the transformation agenda in higher education. 
These policy documents were the Education White Paper 3 (Department of Education 1997) and the National Plan for Higher Education (Department of Education 2001). The two policy documents were linked as the latter was designed to outline the strategy for implementation of the former. The White Paper 3 (Department of Education 1997, 2) stressed the need for the transformation of higher education in South Africa as an imperative in order to address past inequalities (see also Baloyi and Naidoo 2016, 26).

One of the key drivers of the transformation agenda at higher education institutions was the mergers of institutions during the 2000s. The term merger, as used in the higher education context, was defined by Hall, Symes and Leucher $(2004,2)$ as

"the combination of two or more separate institutions into a single new organisational entity, in which control rests with a single governing body and a single chief executive body, and whereby all assets, liabilities, and responsibilities of the former institutions are transferred to the single new institution."

Scholars such as Baloyi and Naidoo $(2016,26)$ argued that the link between the transformation policy in higher education and the mergers of institutions was driven by several key factors, namely access, equity and redress in order to instil social justice; effective and efficient use of resources; and the institutionalisation of a culture of knowledge and information. In other words, the merger process was designed to restructure higher education at an institutional level, in order to facilitate transformation as defined by the post-1994 dispensation. Hall et al. (2004, 11) described the merger process as a deliberate state-driven strategy: "Mergers ... have been prescribed by the state as part of an explicit agenda of transformation, redress and equity in the sector". In this sense, the mergers can be seen as the beginning of the decolonisation process at HEIs. Thus, transformation and the merger process, as well as decolonisation are not merely a conflation. They are all part of the same process. Decolonisation is the perceived result, while transformation and the merger processes are seen as the mechanism through which to achieve the end result.

The ideological contestation within higher education institutions that has currently manifested in the Rhodes Must Fall and Fees Must Fall movements, was already noticeable during the merger processes, albeit at a more subdued level. This is evidenced by several scholars of the transformation agenda in higher education who made reference to the resistance of some institutions to fully implement the government's higher education transformation policy. According to Baloyi and Naidoo $(2016,26)$, for example, "In the South African context, the mergers were more politically-driven, resulting in some resistance initially". In a similar vein, Kamsteeg $(2016,1)$ argued that in spite of major government-driven restructuring in 
higher education institutions, many of them have shown a notoriously slow pace of change. Cloete and Moja $(2005,704)$ identified several tension points in the higher education transformation process, one of which was the idea that the transformation discourse overly stressed racial equity at the expense of efficiency. Although there can be little argument against the fact that some improvements have been made since the merger processes initially began, the structural changes and perceived improvements did not necessarily negate the ideological tensions at the root of transformational issues.

One of the more infamous examples illustrating the above was the case of the Reitz Four, as they were called in the media, and its aftermath. In 2007, four white University of the Free State students, staying in the Reitz men's residence, became embroiled in controversy after they were accused of making a racist video showing the mock initiation of several black cleaning staff. The students were expelled, fined and pled guilty to crimen injuria (Morkel and Mnguni 2010). However, a later incident, in 2009, involved a video of four white students undergoing a humiliating initiation ritual in a predominantly black student hostel at the same institution. An anonymous source claimed in the media that those behind the leaked video wanted to "harm integration efforts at the university", and sought to "preserve white culture and benefits at the university" (Morkel and Mnguni 2010).

In a more recent example, this time at UCT, a new controversy has emerged surrounding another perceived colonial symbol, a sculpture of Saartjie Baartman. In the latest incident, a UCT librarian catalysed a debate regarding the uncovering of the sculpture which had been wrapped up in cloth by student protesters since 2016 (Pertovsky 2018). While some lauded the librarian's act to uncover the sculpture, others have criticised and denounced the move. For example, one senior UCT academic remarked, "Why would a white man see the need to derobe a sculpture in order to expose a naked Sarah Baartman yet again?" (Pertovsky 2018). The university's Works of Art Committee (WOAC) plans to hold a public meeting to engage the issue. The point is that even in this recent example, the underlying ideological contestation alluded to above still has an impact on the interpretations of symbols at UCT.

\section{DECOLONISED EDUCATION: PERSPECTIVES AND CONTRADICTIONS}

The issue of decolonised education in Africa has been a topic of scholarly discussion and debate for a long time (see, for example, Seepe 2001; Teffo 2000; Vilakazi 2002; Chilisa 2012; Higgs 2012; Le Grange 2016). It has formed part of the broader African Renaissance, so much so that it was identified by former South African president Thabo Mbeki as an integral factor in the realisation of social and economic development and success on the continent (Mbeki 1999). At the heart of the issue is the already identified ideological contestation between the Eurocentric 
(that is colonial) influence on education and the move towards the Africanisation (that is decolonising) of education.

Scholars such as Higgs $(2012,37)$ have argued that "The marginalisation of African values in African education has resulted in the general Westernisation of education theory and practice in Africa ...". This alludes to the point made earlier about the motive behind the Rhodes Must Fall movement. The marginalisation of African values in education has engendered the perceived Eurocentric institutionalised culture in higher education institutions that is characterised by institutionalised racism and other issues. Hence, the call for decolonisation that emerged from the student protests from 2015 was a call to radically strike at the core of what was perceived to be the main reason for the disadvantaging of African students in higher education.

Various perspectives emerged during media reports on decolonisation in education in South African universities. For example, Evans (2016) reported on an interview conducted with one of the UCT student protesters in September 2016. When asked what the students meant by decolonised education, the student alluded to several of what he considered to be the main issues. Some of these included the idea that the

"current curriculum dehumanises black students; We study all these dead white men who presided over our oppression, and we are made to use their thinking as a standard; decolonisation advances the interests of Africans instead of the interests of Europeans; and we cannot be decolonised by white people who colonised us; decolonised education is not the same as transformed education; for decolonised education to be introduced, the existing system must be overthrown and the people it is supposed to serve must define it for themselves" (Evans 2016).

The Design Education Forum of South Africa (DEFSA) disagreed with some of the views expressed above, although it concurred with others. According to Mgqwashu from DEFSA (2016), it was not possible for universities to decolonise without first clearly defining what is meant by decolonisation of the curriculum. This issue was still a "grey area" as it was unclear whose responsibility it was to undertake this process. However, Mgqwashu (2016) was in agreement with the above student's view that decolonisation and transformation are not the same thing. Furthermore, according to Mgqwashu (2016), decolonisation was not about "one particular group claiming custodianship", but rather that "White South African academics are as vital in driving genuine curriculum decolonisation as their black peers". This view appears contrary to that of the UCT student, who clearly indicated that decolonisation cannot be done by white academics and students.

Another social commentator, who goes by the pseudonym Logical Knowledge, attempted to highlight the inherent contradictions in the student protesters' understanding of decolonised 
education. According to the commentator, the students were fighting for decolonisation, yet they wore clothing that were "very expensive branded Western cloth" (Logical Knowledge 2016). Furthermore, the commentator posed the following questions:

"I cannot help but wonder what decolonised education entails. If it does not include Maths, Science, Biology, Engineering, Industrial progression what are you fighting for and about? Why do you want free education in something you don't believe in? Why are you using a cell phone, computer and the internet? It [sic] is colonised." (Logical Knowledge 2016).

According to Warburg (2016), "decolonised education was a semantic obscenity and wrecking ball of higher learning". Taking a very critical view of the decolonisation movement, Warburg (2016) described it as "tragic" that "certain elements" within higher education institutions sought to reject available knowledge because of the identity or race of those presenting this knowledge. The motive for his scathing critique emanates from his perception of the radical nature of the decolonisation movement. He argued thus:

"There is obviously no prospect of debate or rational dialogue with such a mindset. Minds have been made up .... They are minds that conjure up ideologies, dogmas and counter-intellectual ideas which ... have become coercive and abusive of others. The facts of history and the evolution of our imperfect society are reduced to "one liners" that not only close their eyes to a balance of views, but invoke fictional notions." (Warburg 2016).

The polarisation of perspectives that the above views illustrate suggest that the issue of decolonised higher education is fraught with ideological contestation, the most notable of which is Afrocentric versus Eurocentric education. Quite rightly, those in favour of decolonisation argue that the current system is fundamentally flawed in that it has indoctrinated African students and academics into colonialist/Eurocentric thinking. However, if one looks at the contrary perspectives, would the proposed decolonised education, as envisaged by the student protesters, not be yet another form of indoctrination? On the face of it, it would seem that none of the views of the pro-decolonisation students, as alluded to above, can accommodate, willingly or otherwise, anything outside of an Afrocentric ideological basis. Warburg's sentiments appear to support this view. The minds that have been made up are not open to any debate or dialogue; there is no room for accommodating or even hearing alternative perspectives.

In other words, the radical views of decolonisation suggest that they are based on an indoctrinated perspective, where the rights of others who do not share this view or who do not participate in radical activities are ignored. The student protests created an environment where the protesters' rights were deemed to be more important than the rights of those who chose not to participate, even if they were in support of the principles underlying the protests. In a report 
by Raborife (2016), a doctoral student at the University of Pretoria expressed her frustration at the negative impact of the disruptions caused by the protests: "For us to hold this academic year is completely unfair. It doesn't work. It affects employers, it affects a whole lot of people." However, a student protest leader at the same institution stated that "[T] $[$ he rights of the few cannot be trumped over the rights of the many that are refused entrance into the university" (Raborife 2016).

The obvious question in this situation, seems to be: whose rights should take precedence? Those of the non-participating students, or those of the protesters? It is a difficult question to answer as the rights of both groups are equally important. However, an indoctrinated mindset does not see this, as it is the dominant narrative, and those who champion it, whose rights matter the most. There is thus no willingness to explore or even consider alternatives that could, at the very least, make as little an infraction as possible on the rights of all involved, and not single out any one group for preferential treatment over others. The irony is that while Eurocentric indoctrination has done this, the proposed decolonisation agenda appears to be going down the same path, especially if radical elements are allowed to dominate the direction and pace of decolonisation.

\section{CONCLUSION}

The intention of this discussion was to illuminate the point that the crisis in higher education in South Africa is not really about fees, although this is one of the key issues. Fees and related issues are a part of a much larger issue which, as has been argued, is the actual cause of the crisis. The crisis is about the ideological contestation between Eurocentrism and Afrocentrism at higher education institutions. But the crisis goes even deeper than this. It is about universities being involved in indoctrination rather than education. As the examples in the US illustrated, the ideological contestation raises questions about what institutions of higher learning are actually doing. Are they engaged in education, or indoctrination?

The discussion has shown that the answer to this question is not that clear because the issue of education or indoctrination depends on which ideological position one chooses. The pro-decolonisation protesters clearly articulated the view that the current colonial-inherited institutional and learning culture at universities has been indoctrinating African students and staff into a Eurocentric way of thinking, and that this has little to no relevance for resolving African issues. In contrast, those arguing against decolonisation claim that Afrocentrism is a radical position that has no place for alternative perspectives. Both arguments have merit, and if they teach us anything, it is that a rigid adherence to either ideological position produces an environment for indoctrination rather than education. Hence, calls for radical decolonisation 
risk creating the same circumstances for indoctrination in educational institutions that Eurocentric influences have done. It is thus the contention of this article that decolonisation should be treated and approached with caution. If not, then, at least as far as higher education is concerned, the oppressed may find themselves becoming the oppressors.

\section{REFERENCES}

Baloyi, M. C. and G. Naidoo. 2016. Higher education mergers in South Africa: A means towards an end. African Journal of Public Affairs 9(3): 19-29.

Chaudhuri, A. 2016. The real meaning of Rhodes must fall. The Guardian, 16 March. https://www.theguardian.com/uk-news/2016/mar/16/the-real-meaning-of-rhodes-must-fall (Accessed 22 February 2018).

Chilisa, B. 2012. Indigenous research methodologies. Los Angeles: Sage Publications.

Cloete, N. and T. Moja. 2005. Transformation tensions in higher education: Equity, efficiency and development. Social Research 72(3): 693-722.

Crouere, J. 2016. Liberal indoctrination trumps education at US colleges. Townhall, 10 December. https://townhall.com/columnists/jeffcrouere/2016/12/10/liberal-indoctrination-trumps-educationat-us-colleges-n2257882 (Accessed 15 February 2018).

Department of Education. 1997. Education White Paper 3: A programme for the transformation of higher education. Government Gazette, 390(18515). Pretoria: Government Printers.

Department of Education. 2001. National Plan for Higher Education (NPHE). Pretoria: Department of Education.

Du Preez, P., S. Simmonds and A. H. Verhoef. 2016. Rethinking and researching transformation in higher education: A meta-study of South African trends. Transformation in Higher Education 1(1). http://dx.doi.org/10.4102/the.v1i1.2 (Accessed 27 February 2018).

Encyclopaedia Britannica. 2018. Brainwashing. https://www.britannica.com/topic/brainwashing (Accessed 2 February 2018).

Evans, J. 2016. What is decolonised education? News 24, 25 September. https://www.news24.com/ SouthAfrica/News/what-is-decolonised-education-20160925 (Accessed 6 March 2018).

Hall, M., A. Symes and T. Leucher. 2004. The governance of merger in South African higher education: $A$ research report prepared for CHE. Pretoria: Council on Higher Education.

Heleta, S. 2016. Decolonisation of higher education: Dismantling epistemic violence and Eurocentrism in South Africa. Transformation in Higher Education 1(1): a9. http://dx.doi.org/ 10.4102/the.v1i1.9.

Higgs, P. 2012. African philosophy and the decolonisation of education in Africa: Some critical reflections. Educational Philosophy and Theory 44(S2): DOI: 10.1111/J.1469-5812.00794.x.

Hocutt, M. 2005. Indoctrination v. education. Academic Questions 18(3): 35-43.

Kamsteeg, F. 2016. Transformation and self-identity: Student narratives in post-apartheid South Africa. Transformation in Higher Education 1(1): a10. http://dx.doi.org/10.4102/the.v1i1.10 (Accessed 1 March 2018).

Kenny, J. 2013. Higher education: Brainwashing 101. The New American, 24 July. Available at https://www.thenewamerican.com/culture/education/item/16053-higher-educationbrainwashing-101 (Accessed 20 February 2018).

Le Grange, L. 2016. Decolonising the university curriculum. South African Journal of Higher Education 30(2). http://dx.doi.org/10.20853/30-2-709 (Accessed 6 March 2018).

Logical Knowledge. 2016. Colonised universal branding. News 24, 24 October. https://www.news24. com/MyNews24/colonised-universal-branding-20161024 (Accessed 7 March 2018). 
Mart, C. T. 2011. British colonial education policy in Africa. International Journal of English and Literature 2(9): 190-194.

Mbeki, T. 1999. Speech to the Conference on Education for African Renaissance in the $21^{\text {st }}$ Century, 6 December. Johannesburg.

McDonough, T. 2011. Initiation, not indoctrination: Confronting the grotesque in cultural education. Educational Philosophy and Theory 43(7): 706-723.

Mgqwashu, E. 2016. Universities can't decolonise the curriculum without defining it first. Design Education Forum of Southern Africa. http://www.defsa.org.za/articles/universities-can\%E2\% 80\%99t-decolonise (Accessed 6 March 2018).

Morkel, P-A. and H. Mnguni. 2010. Media ban after new UFS video. News 24, 3 August. https://www.news24.com/SouthAfrica/News/Media-ban-after-new-UFS-video-20100803 (Accessed 1 March 2018).

National Association of Scholars 2012. A crisis of competence: The corrupting effect of political activism in the University of California. Princeton: National Association of Scholars.

NAS see National Association of Scholars.

Pertovsky, N. 2018. Quarrel over Sarah Baartman statue at UCT. News 24, 3 March. https://www.news 24.com/SouthAfrica/News/quarrel-over-sarah-baartman-sculpture-at-uct-20180303 (Accessed 5 March 2018).

Raborife, M. 2016. The rights of the few to study do not trump the rights of the many who can't, says UP student. News 24, 10 October. https://www.news24.com/SouthAfrica/News/the-rights-of-thefew-to-study-do-not-trump-the-rights-of-the-many-who-cant-says-up-student-20161010 (Accessed 7 March 2018).

Reddy, T. 2004. Higher education and social transformation: South Africa case study. http://www.che.ac.za/sites/default/files/publications/HEandSocialTransformationReport_25Feb2 004.pdf. (Accessed 29 January 2018).

Seepe, S. 2001. Indigenous knowledge systems can benefit everyone. Mail and Guardian, 21 October.

Tan, C. 2011. Islamic education and indoctrination: The case in Indonesia. New York: Routledge.

Teffo, L. J. 2000. Africanist thinking: An invitation to authenticity. In African voices in education, ed. P. Higgs, N. C. G. Vakalisa, T. V. Mda and N. T. Assie-Lumumba. Cape Town: Juta.

Warburg, M. 2016. "Decolonised" education - semantic obscenity and wrecking ball of higher learning. News 24, 5 October. http://voices.news24.com/martin-warburg/2016/10/decolonised-educationsemantic-obscenity-wrecking-ball-higher-learning/ (Accessed 7 March 2018). 